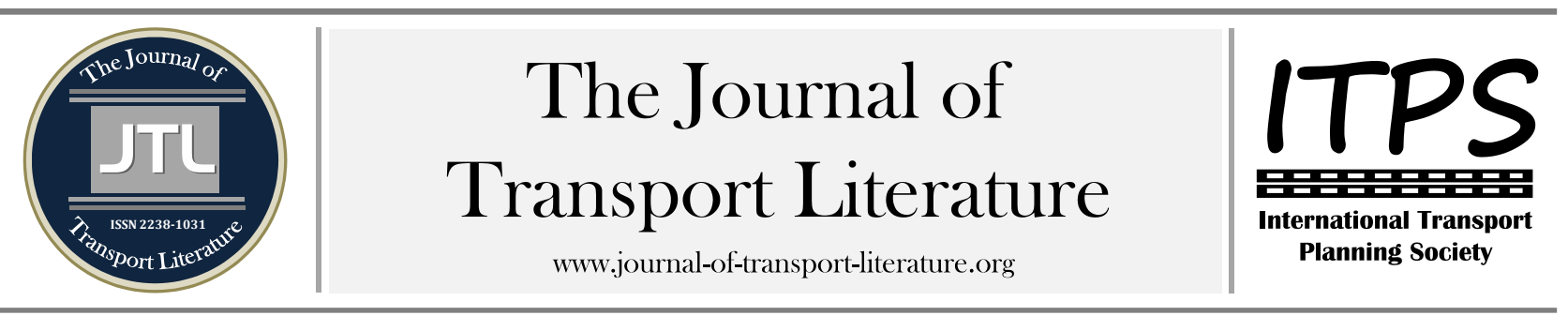

\title{
Measuring accessibility: effects of implementing multiple trip generating developments
}

Jessica Helena de Lima+; Maurício Oliveira de Andrade; Maria Leonor Alves Maia Universidade Federal de Pernambuco, UFPE, Recife, Brazil

\section{Article Info}

Keywords:

trip generating development accessibility

indicator

Suape's Industrial and Port

Complex

number of displacements

Submitted 13 Apr 2015;

received in revised form 7 Aug 2015

accepted 31 Aug 2015

Licensed under

Creative Commons

CC-BY 3.0 BR.

\section{Abstract}

The urban environment can be strongly affected by the increased number of displacements that emerge from a trip generating development hub, and so a measuring tool is needed for these variations, indicating where they occurred with a greater intensity. This can guide the government when investing in local transport. This paper proposes location quality indicators and uses them to measure the impact of the new Industrial Port Complex of Suape in Pernambuco, which is considered to be trip generator territory. Data from the 1997 OD survey, prior to the existence of the complex, has been used in comparison with the 2010 Census, once the industries were in place. Clearly the complex installation brought great changes, not only to its immediate location, but also for the entire metropolis. Displacements towards this area have greatly intensified in number and average travel time. The accessibility index for the locals has greatly improved, and their per capita income shows its greatest variation between the years 2000 and 2010, suggesting that local workers have been absorbed by the industry, comprising an important step towards sustainable development and social inclusion.

+ Corresponding author. Av. Prof. Moraes Rego, 1235 - Cidade Universitária, Recife - PE - CEP: 50670-901.

E-mail address: delima.jh@gmail.com.

\section{Introduction}

This paper presents a methodology developed to evaluate the impact of multiple trip generating development in metropolitan areas, using Suape's Port and Industrial Complex as a case study.

Trip generation developments (TGD) are constructions that impact traffic, economic development and people's quality of life (REDEPGV,2005). Multiple trip generation developments (MTGDs) are sets of shops or services close to each other that form "clusters" of activities (Goldner et al., 2010). Specialists claim that TGDs affect the infrastructure and urban traffic, by attracting various services and people, and generating negative effects on mobility (Mendes \& Sorratini, 2014). Others defend them by noting that they cause both positive impacts, by enabling development and enhancing areas, and negative, by affecting mobility and accessibility in the area and its surroundings (Guimarães et al., 2014).

It is therefore important to measure the impact of any MTGD in a region. Recife's Metropolitan Area suffers from data shortage, however. The only source available is an 18 year old OD survey and the 2010 census data. This is a problem in many other cities in the developing world, and there is therefore a need to create a methodology using census data able to measure the impact of such structures on a region's mobility, and its implications for society and economics.

According to the literature, the broad application of accessibility indicators include: Wachs and Kumagai (1973) illustrating their work on accessibility differences as a function of residence and socioeconomic status spatial location; Koenig's (1977) hypothesis using utility to imply that in a given zone individuals rank all possible travel utilities in descending order, they would travel enough to ensure that the utility derived from the last trip is exactly the same as the disutility of not taking the trip; Gutierrez et al. (2010) propose a methodology to measure spatial spillovers of investment in transport infrastructure and monetize them, allocating the costs of the planned infrastructure in accordance with the regional distribution of the potential benefits of accessibility; and Lima Neto (1982), whose concept was adopted in this article, considers accessibility as a location quality index, displaying the greater or lesser ease of access opportunities, considering transport system characteristics, and the number of activities within the reach of such activities.

In this context, a methodology based on opportunities for accessibility has been designed, aimed at identifying and measuring the impact of trip generation development hubs on factors that influence the greater use of road over rail transport in Brazil. The methodology is a useful tool for current scenario analysis and for planning transport infrastructure.

Section 1 presents the study area and its particularities, Section 2 introduces the structured scientific methodology used for analysis unfolding the research, Section 3 describes the study's main findings and lastly, the section headed "Conclusion" presents the paper's final remarks. 


\section{Recife's Metropolitan Area and Suape's Port and Industrial Complex}

Located in Northeast Brazil, the metropolitan area of Recife encompasses fourteen municipalities, including the fifth largest in Brazil, with a population of 4,046,845 inhabitants (IBGE, 2013). It is also the third most densely populated metropolitan area in the country, surpassed only by São Paulo and Rio de Janeiro, and the fourth largest urban network in Brazil (IBGE, 2013). Recife is the municipality with the highest per capita monthly income (U\$442), followed by Olinda (U\$ 270) and Jaboatão Guararapes (U\$ 246). The poorest are the municipalities of São Lourenço da Mata (U\$ 106) and Araçoiaba (U\$ 111). The region has a low income per capita when compared to São Paulo (U\$ 606), Brasilia (U\$ 686) or Rio de Janeiro (U\$ 597) (IBGE, 2014).

According to Lima and Maia (2014) land use in the Recife metropolitan area does not obey the center-periphery occupation pattern (European) or the periphery-center occupation pattern (US). Slums and poor communities are scattered throughout the municipalities, in conurbation with the richest neighborhoods. In the capital, all areas are at most within 1 $\mathrm{km}$ of a slum area (Lucas et al., 2013).

Between 1997 and 2012, the vehicle fleet in the Recife Metropolitan Area RMR increased 49\%, jumping from 745000 to 1.11 million. In the same five years the population of RMR grew only 16\% (IBGE, 2014; DENATRAN, 2014). Moreover, motorcycle's share has increased substantially, going from $6.7 \%$ of the fleet in 1990 to $20.5 \%$ in 2010 . Over the same period, the number of cars decreased from $78.3 \%$ to 63.5\% (Andrade et al, 2015). These phenomena are seen in harmful social problems such as increasing the number of motorcyclists involved in serious accidents and a decrease in the demand for public transport, reducing productivity and increasing costs.

The recent economic performance of Pernambuco State was greater than that of Brazil itself: between 1997 and 2011 the Pernambuco GDP grew 34\% more than the national GDP. Much of the growth is attributed to the blunt opportunities created by investments in Suape's Port and Industrial Complex (SIPC), located in the municipalities of Ipojuca and Cabo de Santo Agostinho, as seen in Figure 1. It is considered one of the country's leading investment centers, whose 120 companies located across 13.5 thousand hectares, is the main hub of Northeast Brazil business, generating 25000 direct jobs, with 50 other companies under construction. The fields of interest are varied, including: chemicals, metalworking, shipbuilding and logistics, bulk liquids and gases, food and wind power (Lima et al., 2014).

Until the 1990s, the economy of the SIPC area was based on the agribusiness of sugarcane. In recent years, sizeable public and private investments settled and consolidated a large industrial and logistics hub, causing a significant transformation in the region's economic profile. New companies are being drawn to the region, billions of dollars have been invested and the demand for labor grows annually, particularly in the building of industrial facilities, and the necessary road, energy and port infrastructure. The low levels of professional training in inhabitants of the surrounding municipalities has meant a strong migration of labor from other regions and other cities in the metropolitan region, generating great demand for mobility that is not supported by the existing road system and current transport, and whose expansion, although planned, was not completely fulfilled. Despite the undeniable economic advantages offered by this rapid growth, this situation has gradually had serious negative externalities in the SIPC region, one being a significant loss in the quality and reliability of mobility and transport security. Although the SIPC relies on a set of arterial and collector roads, travel times and traffic jams of many kilometers are increasingly becoming routine at all times on work days. Studies by PETROBRAS in 2009 showed levels of service between D and E in most days. With the intensification of works in the following years, the situation has worsened, with the most critical sections of the highways operating at F level overcapacity (Meira et al., 2012).

SIPC's biggest mobility problem is the supply of public transport; only one line connects the complex to the Integrated Terminal of Cabo de Santo Agostinho, where it's possible to travel anywhere in the metropolitan area by paying for a single ticket (U\$ 1) using the Structural Integrated System (SEI) of the two main lines, from Cabo to the airport and from Cabo to Recife Center. Each day, approximately seven thousand people travel through the Cabo Integration Terminal, a meager amount compared to the estimated 70,000 workers reaching SIPC every day.

\section{Methodology}

In an effort to measure the accessibility of each city in Recife's Metropolitan Area, using the most recent data from 2010 and comparing it with the situation in 1997, we created an indicator that describes the location, distribution and intensity of activities, and transport characteristics. This indicator was based on the one proposed by Lima Neto (1982) for the city of Recife. The following procedures were adopted.

\subsection{Indicators}

The proposed indicator is based on accessibility indicators proposed by Mäcke (1974) and Wachs and Kumagai (1973), allowing consideration of travel time between cities, network and transport system characteristics, and the spatial distribution of activities in the Metropolis, evaluating the interaction between transport and land use. The information available was also a determinant in creating this indicator.

Where:

$$
Q_{i p}=\left(\sum_{j=1}^{n} X_{i j p} 10^{3}\left(W_{i j p}\right)^{-1}\right)
$$

- $Q$ = location quality or accessibility index of the destination city i with the purpose p;

- $\mathrm{i}=$ destination city index;

- $\mathrm{p}=$ trip purpose;

- $\mathrm{j}=$ travel time index;

- Xijp= percentage or intensity of urban structures;

- Wip= impedance function or difficulty in accessing the city for purpose $\mathrm{p}$.

The variation in accessibility level calculations in the two years considered was calculated based on the previous index, but considering origin and destination cities. 
Where:

$$
Z_{f i}=\sum_{i=1}^{n} W_{i p A}-\sum_{i=1}^{n} W_{i p B}
$$

- $\mathrm{Z}=$ variation in travel time from city i to purpose $\mathrm{p}$;

- $\mathrm{f}=$ kind of relationship with city $\mathrm{i}$;

- $\mathrm{i}=$ destination city index;

- $\mathrm{p}=$ trip purpose;

- $\mathrm{A}=$ base year;

- $\mathrm{B}=$ analysis year;

- Wip= impedance function or difficulty accessing city for purpose $\mathrm{p}$.

\subsection{Data gathering}

Once the calculation of indicators was defined we obtained the necessary data: number of trips attracted by each destination, the socio-economic indicator that represents the structure or activity located in each destination zone, and the variable used in the impedance function, travel time to work. The reason we chose the motive as being work and the specific time periods of 1997 and 2010 was the data available.

For 1997 we used the last origin-destination research for the Recife Metropolitan Area by the Urban Transport Metropolitan Company (EMTU) in 1998. For 2010 the data used was the Census 2010 microdata (the most recent issue), obtained directly from IBGE. This research was the first to encompass individual travel time to work, allowing a greater range of possibilities for transport research involving demographic microdata.

\subsection{Impedance function calculation}

Impedance function was determined following Mäcke's (1974) concept. According to this author, accessibility should be measured through trip frequency according to expenditure class (for example, time or distance). The chosen trip purpose was "work" and the impedance was taken as the travel time to work for each individual considering the working population that commuted daily, going to and returning from work on the same day. The impedance functions were subsequently determined, calculated to each destination city.

Thereby, Trips were grouped according to travel time classes defined by the Brazilian Geographical and Statistics Bureau (IBGE). Class 1 represents trips of less than 5 minutes travel time, Class 2 represents trips between 5 and 30 minutes, Class 3 encompasses trips between 30 minutes and 1 hour, Class 4 between 1 and 2 hours, and Class 5 more than 2 hours. The number of trips attracted to each municipality was then weighted using the average number of minutes needed in every class.

To determine the municipalities which have better access or location quality, and how this indicator has changed from 1997 and 2010, we considered trips to work, the only possibility using census data from 2010. Thirteen of the fourteen municipalities in the metropolitan area were analyzed. Araçoiaba was not considered due to inconsistencies in the data.

\section{Relative accessibility of municipalities affected by SPIC: results}

Based on the methodology, this paper quantitatively examines the accessibility level of each municipality in Recife's Metropolitan Area, as well as the impact caused by the creation of a new trip generation territory in an area that was previously rural in nature, through an adaptation of an indicator which allows longitudinal analysis based on the variation of jobs and travel time to work between 1997 and 2010, in the municipalities of the region.

We measured the percentage of total trips generated and attracted in thirteen municipalities, specifically attempting to verify the impact of the Port and Industrial Complex classified as TGD. Figure 1 measures the location quality index for 2010 to trips attracted with work purpose to the given municipalities. The indicator considers the percentage of trips attracted and the travel time to that region. As expected the capital, Recife, stands out as the municipality most accessible for work purposes. Municipalities such as Itamaracá, Itapissuma, and Igarassu also had good accessibility due to their low total travel time, most people commuting in those cities are restricted to the area they comprise, leveraging the indicator. With the exception of those outliers, the municipalities that stand out are Cabo de Santo Agostinho and Ipojuca, where most of the companies attracted by SIPC are located representing a high level trips for work reasons, since all municipalities from the Metropolitan Area displaced in that direction in 2010, contrastingly with what was observed for 1997. Of the inhabitants of Recife, only $0.003 \%$ and $0.16 \%$ commuted daily to Ipojuca and Cabo de Santo Agostinho respectively in 1997, compared to $0.53 \%$ and $0.71 \%$ in 2010 .

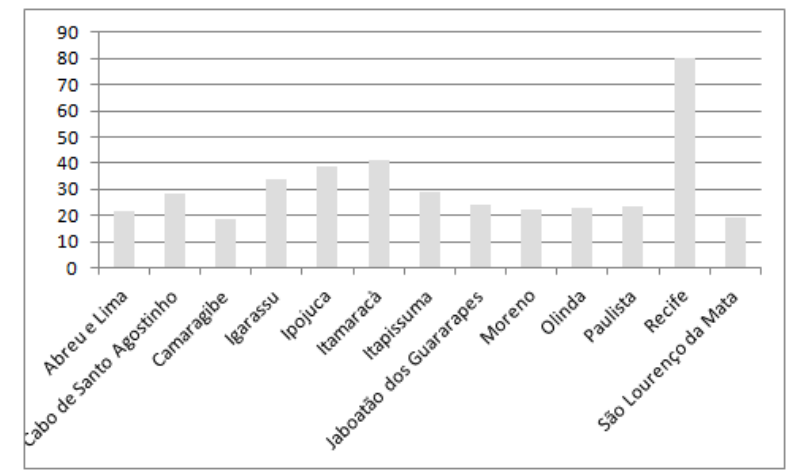

Figure 1 - Location quality index

Source: own calculation 
The economic growth of the cities closest to SIPC after 2000 was remarkably accelerated and the transport infrastructure did not manage to match that slope. Figure 2 presents the variations in accessibility between 1997 and 2010 for individuals who lived in each municipality. It can be seen that the municipalities that vary negatively in relation to travel time were those from the south area, which were more affected by the port complex, meaning that people who lived in those areas started spending less time travelling than the others. In Cabo de Santo Agostinho and Ipojuca this is explained by the great increase in jobs on offer, allowing almost all the working residents to have formal jobs in the region. 85\% of the people living in Cabo de Santo Agostinho and 98\% of the people living in Ipojuca in 2010 worked in one of the two municipalities. The negative variation of Jaboatão dos Guararapes can be explained by the decrease in the average time spent traveling by the inhabitants who worked in Recife.

The negative variation of Jaboatão Guararapes is explained by the decrease in average travel time of the inhabitants of this area who worked in the capital (39\%), from 84 to 54 minutes. Although it appears strange, there was a decrease in travel time for the inhabitants of Recife working in all 13 municipalities, due to the decrease in travel time of people who live and work in the capital (93\%) of 39 to 33 minutes. This may have occurred due to the expansion of the subway to the south of Recife, a big commuting attraction hub as well as improving the traffic on the main roads of the area. It can be inferred that the rapid constructive densification occurring in the last 10 years in Recife allowed the population to live closer to their worksites, reducing travel times.

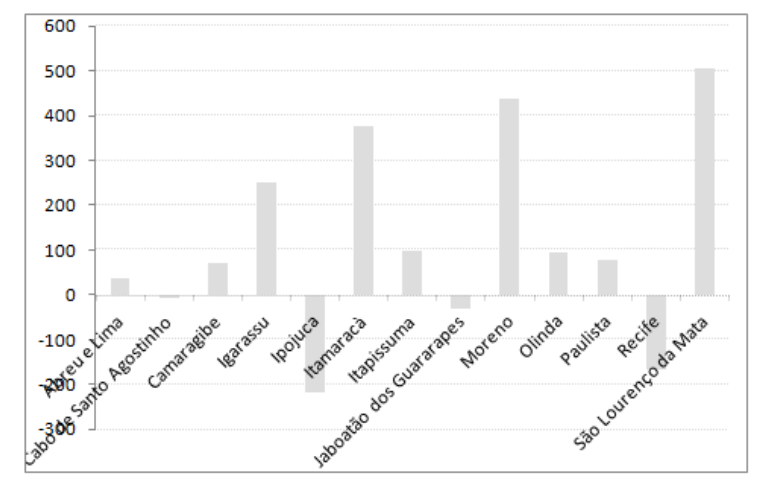

Figure 2: Differences in accessibility of origin cities (1997-2010) Source: own calculation

Figure 3 shows variation in the level of accessibility of the people working in each municipality between 1997 and 2010. Again the municipalities of Cabo de Santo Agostinho and Ipojuca stand out, but this time in the opposite direction, suggesting that there was a significant increase in the average commuting times for people in all municipalities of the Recife Metropolitan Area. Two phenomena illustrate this: the lack of transport infrastructure and the rapid increase in the number of people traveling daily to the region. In this regard it is important to highlight the delay in the daily operation of the Light Rail Vehicle (LRV) of CBTU (Brazilian Urban Rail Company), connecting Cabo de Santo Agostinho's integration terminal and Suape's passenger terminal to the Integrated Structural System (SEI), and specifically to Recife Metro's south line. The operation of these trunk lines should mitigate the long travel times of resident workers in the most remote metropolitan municipalities.

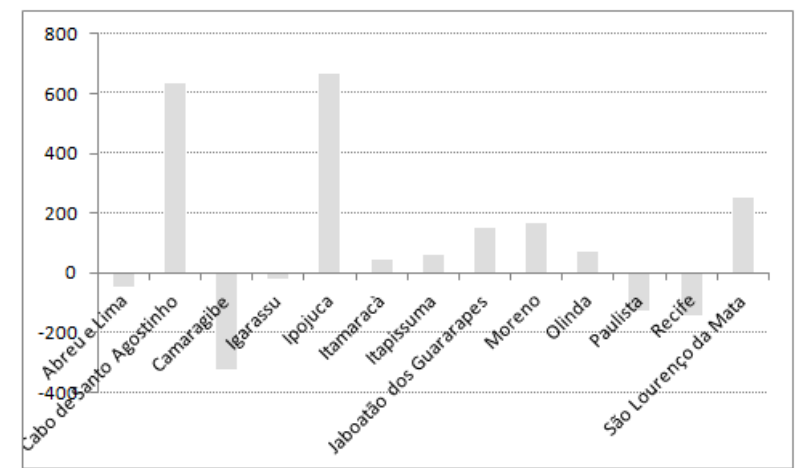

Figure 3: Differences in accessibility of origin cities (1997-2010) Source: own calculation

There is thus enough evidence to say that Suape's Port and Industrial Complex is a MTGD, influencing the economic and social dynamics of its surrounding inhabitants as well as the inhabitants of Recife's Metropolitan Area, who began to commute to the complex. The average commuting time for these cities increased from 67 to 85 minutes to Cabo de Santo Agostinho, and from 68 to 83 minutes to Ipojuca.

\section{Conclusion}

The aim of this paper was to evaluate the impact of a trip generation development hub on the social and economical dynamics of a metropolitan area using an accessibility indicator and microdata from the census.

Applying the methodology developed in this study has provided insight into the significance of infrastructural investments such as SPIC in a region, and created a portrait of traffic and workforce flow in Recife's Metropolitan Area. 
The installation of SPIC in the southern region RMR clearly brought great changes, not only to the hosting municipalities, but for the entire metropolis. Such a result can be seen in the increased displacement of workers to the area, and verified by the huge difference between travel times for the cities of Cabo de Santo Agostinho and Ipojuca between the years 1997 and 2010.

The results of this study also indicate that accessibility greatly improved for locals, and per capita income showed the greatest variation between 2000 and 2010 in RMR, growing 73\% in Ipojuca and 75\% in Cabo de Santo Agostinho (Lima et al., 2014) suggesting that the inhabitants of the region were absorbed by adjacent industries, contradicting Cavalcanti's prediction (2004). This is highly significant given that the reduction of social inequality is a key factor for sustainable development in a locality.

The major limitation of the model developed was the small amount of data concerning mobility in the region. The OD survey is old but large and the census data provides very limited information, and only about the municipality, and not the area where individuals work. This prevents an interesting application of the indicator: a zone-area survey to analyze in more detail the changes in accessibility in smaller areas and their relationship with land use and occupation.

The methodology presented in this paper is general enough to be applicable to other related research. It is suggested that future studies of the topic should analyze TGD impact in several metropolitan areas; some cities already have periodical OD research, others will have to wait for Census 2020 to have comparable data. It would also be possible to analyze the power of a centrality within a region attracting commuting trips from a broader area.

\section{References}

Andrade, M., Lima Neto, O., Maia, M.L. A. M \& Meira, L. H. (in press 2015) Como Anda A Região Metropolitana Do Recife. Observatório Das Metrópoles.

Cavalcanti, J.C. (2004) Educação Em Pernambuco: O Modelo Tem Que Mudar? Retrieved from: www.economia.pe.gov.br

CONDEPE/FIDEM (2014) PIB Estadual. Retrieved from: <http://www.condepefidem.pe.gov.br/web/condepe-fidem/estadual>.

DENATRAN - Departamento Nacional de Trânsito (2014) - Frota. Retrieved from: http://www.denatran.gov.br/frota.htm

Guimarães, V. A., Leal Junior, I. C., D'Agosto, M. A., Ferreira, A. F., \& Oliveira, C. M. (2014). Desempenho ambiental de polos geradores de viagem de carga. Journal of Transport Literature,8(3), 250-269.

Goldner, L. G.; Westphal, D.; Pinto de Freitas, I. M.; Santos, D. V. C. (2010) Pólos múltiplos geradores de viagens (PMGV). Revista Transportes $18(1)$.

Gutierrez, J., Condeço-Melhorado \& A., Matin, J. C. (2010) Using accessibility indicators and GIS to assess spatial spillovers of transport infrastructure investment. Journal of Transport Geography. Vol 18 (1), 141-152.

Instituto Brasileiro de Geografia e Estatística - IBGE (2013) Estimativas populacionais para os municípios brasileiros em 01.07.2013. Retrieved from < http://www.ibge.gov.br/home/estatistica/populacao/estimativa2013/estimativa_dou.shtm >. Access: 03 June 2014.

Instituto Brasileiro de Geografia e Estatística - IBGE (2014) Cidades. Retrieved from: www.cidades.ibge.gov.br/

Koenig G. (1977) Les indicateurs d'accessibilites dans les studes urbaines: de la theorie a la practique. Revue Generale des Routes et des Aerodromes. 533, 5-23.

Lima, J. H. \& Maia, M. L. A (2014) Renda E Tempo De Deslocamento Pendular Na Rmr: Quais As Causas Da Relação De Não Monotonicidade Para A População De Baixa Renda? Proceedings of the XVIII Congresso Latino Americano de Transporte Urbano, CLATPU, Rosário, Argentina.

Lima, J. H.; Andrade, M. O. \& Maia, M. L. A (2014) Como Medir A Variação De Acessibilidade Causada Pela Implantação De Um Território Gerador De Viagens? Proceedings of the XXVIII Congresso Congresso Nacional de Pesquisa e Ensino em Transporte - ANPET, Curitiba, Brazil.

Lima Neto, O. C. C. (1982) Möglichkeiten Und Grenzen Der Übertragung Von Zusammenhängen Und Modellen In Der Grobstädtischen Verkehrsplanung Der Bundesrepublik Deutschland Auf Entwicklungsländer - Dargestellt Na Beispiel De Brasilianischen Stadt Recife (Doctoral dissertation). RWTH Aachen University, Aachen, Germany.

Lucas, K; Maia, M; Marinho, G; Santos (2013) Transport Infrastructure Investment and Regeneration: A necessary but insufficient policy measure for addressing social exclusion in Brazilian cities. WCTR, Rio de Janeiro, Brazil.

Meira, L. H., Andrade, M. O. \& Maia, M. L. A. (2012) Mobilidade Crítica em um território gerador de viagens: 0 Caso do Complexo Industrial Portuário de Suape, Proceedings of the XXVI Congresso Congresso Nacional de Pesquisa e Ensino em Transporte - ANPET, Joinville, Brazil.

Mendes, E. O. \& Sorratini, J. A. (2014). Polo gerador de viagens: análise de um terminal urbano de passageiros anexo a um centro comercial. Journal of Transport Literature, 8(3), 290-307.

Mäcke, P. A. (1974) Personenverkehr In Stadt Und Region - Weiterentwicklung Des Algorithmus Zur Schatzungder Strukturbedingten Nachfrage. In: Stadt Region Land, Schriftenreihe Des Instituts Fur Stadtbauwesen,Rwth Aachen, p. 30.

Rede Ibero-Americana De Estudos De Polos Geradores De Viagens - REDEPGV (2005) Relatório Da 1a Reunião De Trabalho. Universidade Federal Do Rio De Janeiro.

Wachs, M., \& Kumagai, T. G. (1973). Physical accessibility as a social indicator. Socio-Economic Planning Sciences, 7(5), 437-456. 